\title{
Losses in weight and body water in sows after weaning
}

\author{
By P. E. ZOIOPOULOS, J. H. TOPPS* AND P. R. ENGLISH \\ School of Agriculture, 581 King Street, Aberdeen AB9 IUD
}

(Received 17 May 1982 - Accepted 2 March 1983)

\begin{abstract}
1. The loss of body water of eight sows in the $7 \mathrm{~d}$ following weaning was determined using the deuterium oxide dilution technique. Four of the sows had received a concentrate diet in restricted amounts while the other four had been given the same diet mixed with two-thirds its weight of oat husks ad lib. during the whole of the preceding lactation. Certain blood and urine constituents were also measured.

2. Loss of body water was significantly less $(P<0.05)$ than weight loss of fasted animals, but body water losses were considerable in six of the eight animals.

3. Excretion of urinary nitrogen, urea and creatinine and levels of plasma urea were higher, while levels of plasma non-esterified fatty acids and the hydroxyproline index were lower 1 week after weaning compared with values obtained on the day following weaning.

4. These results indicate that in addition to water loss, depletion of body tissue, including protein, occurs in the newly-weaned sow.
\end{abstract}

It is known that soon after weaning, sows lose a considerable amount of weight. Lodge (1959), who was one of the first to report such large weight changes of sows, found that the greater the sow's intake during lactation the larger the loss in weight after weaning. Bowland (1967), in reviewing the energetic efficiency of the sow, stated that this weight loss is probably associated with changes in body water and, if so, introduces a possible error in the calculation of energetic efficiency until its actual composition is determined. More recently, O'Grady et al. (1975) found from the results of a coordinated trial, that although the interval from weaning to mating was of short duration, weight losses were substantial but difficult to interpret.

It is frequently assumed that apart from a reduction in gut fill, most, if not all, of the loss is body water. The main objects of this study were to measure in sows the loss in body water during the week following weaning and to attempt to determine whether any other tissues were depleted. Measurements were made of body water by the deuterium oxide dilution technique (Houseman et al. 1973), following an overnight fast, and certain blood and urine constituents were also studied. Some of the results have been reported in a preliminary communication (Zoiopoulos et al. 1978).

\section{EXPERIMENTAL}

\section{Animals and diets}

Six Large White sows of differing parity and two Large White $\times$ Landrace sows in their second parity were used. They were paired according to breed and parity and an animal in each pair received either restricted amounts of a concentrate diet or the same diet mixed with two-thirds its weight of oat husks and fed ad lib. The composition of the diets is given in Table 1. These diets, in general, resulted in different weight changes of sows during lactation (see Table 2, p. 166). At the time of this experiment it was thought that the excretion of urinary 3-methylhistidine was a useful index of muscle protein breakdown since in rats it had been shown that more than $90 \%$ of 3-methylhistidine in the whole body occurs in skeletal muscle (Haverberg et al. 1975) and that after muscle protein breakdown it is not re-utilized but is rapidly and quantitatively excreted in urine (Young et al. 1972). In order

* For reprints. 
Table 1. Composition of the diets $(\mathrm{g} / \mathrm{kg})$

\begin{tabular}{lcc}
\hline & Concentrate & Oat husk \\
\hline Barley & $867 \cdot 5$ & \\
White fish meal & $80 \cdot 0$ & \\
Soya-bean meal & $40 \cdot 0$ & \\
Vitamin and mineral supplement ${ }^{*}$ & $12 \cdot 5$ & 570 \\
Concentrate diet & 1000 & 400 \\
Oat husks $^{+}$ & & 30 \\
Filtra milk & & 850 \\
Dry matter $^{\dagger}$ & 869 & 113 \\
Crude protein $^{\dagger}$ & 168 & 142 \\
\hline Crude fibre & $34 \cdot 9$ & \\
\hline
\end{tabular}

* The supplement provided the following quantities $(/ \mathrm{t}$ mixed diet): retinol $3.6 \mathrm{~g}$, cholecalciferol $0.04 \mathrm{~g}$, $\alpha$-tocopherol $10 \mathrm{~g}$, menadione $2 \mathrm{~g}$, riboflavin $4 \mathrm{~g}$, pantothenic acid $10 \mathrm{~g}$, nicotinic acid $20 \mathrm{~g}$, cyanocobalamin $12 \mathrm{mg}$. Minerals: calcium $2.7 \mathrm{~kg}$, phosphorus $0.3 \mathrm{~kg}$, sodium $0.98 \mathrm{~kg}$, iron $100 \mathrm{~g}$, zinc $100 \mathrm{~g}$, manganese $40 \mathrm{~g}$, copper $17.5 \mathrm{~g}$, iodine $2 \mathrm{~g}$, cobalt $0.5 \mathrm{~g}$, selenium $0.1 \mathrm{~g}$.

$\dagger$ Binding agent which is a whey extract based on lactate.

$\ddagger$ On a dry matter basis.

to avoid a dietary source of 3-methylhistidine, i.e. fish meal, without changing the crude protein (nitrogen $\times 6.25$ ) content the amount of soya-bean meal was raised to $140 \mathrm{~g} / \mathrm{kg}$ and the barley adjusted to $847.5 \mathrm{~g} / \mathrm{kg}$ in the concentrate diet. This diet was fed for $5 \mathrm{~d}$ before weaning either in restricted amounts to one sow in each pair or ad lib. in the mixture with oat husks, described earlier, to the other sows. After weaning all the sows received daily $2 \cdot 3 \mathrm{~kg}$ of this new concentrate diet only.

The feed intake and performance of the sows during lactation has been described elsewhere (Zoiopoulos et al. 1982).

\section{Management of sows and infusion and sampling procedures}

On the morning of the 49th day of lactation the piglets were removed from the sows, the sows were weighed and fitted with a venous catheter in the ear to a depth of approximately $450 \mathrm{~mm}$ according to the procedure described by Anderson \& Elsley (1969). On the day after weaning and 1 week later, total body water (TBW) of each sow was estimated by using the $\mathrm{D}_{2} \mathrm{O}$ dilution technique. On each occasion the sow was deprived of food for $26 \mathrm{~h}$ and water for $18 \mathrm{~h}$ and after $14 \mathrm{~h}$ of fasting the sows were weighed.

$\mathrm{D}_{2} \mathrm{O}$ (Norsk Hydro, Oslo, Norway) with a purity of $99 \cdot 8 \%$ and containing $9 \mathrm{~g}$ sodium chloride $/ \mathrm{kg}$ was infused through the catheter in quantities of approximately $1.0 \mathrm{~g} \mathrm{D}_{2} \mathrm{O} / \mathrm{kg}$ body-weight. The rate of infusion was approximately $15 \mathrm{ml} / \mathrm{min}$ and the amount of $\mathrm{D}_{2} \mathrm{O}$ administered was obtained by weighing before and after infusion. Approximately $20 \mathrm{ml}$ heparinized saline $(9 \mathrm{~g}$ sodium chloride/l) were flushed through the catheter to remove any remaining $\mathrm{D}_{2} \mathrm{O}$.

Before the isotope was administered on each occasion, a sample of blood was taken to serve as a blank. Blood samples were then collected at two hourly intervals until the tenth hour after infusion; plasma and serum were separated and stored at $-20^{\circ}$ for analysis. The sows were weighed after the second blood sample following the infusion had been collected. The mean of this weight and that recorded before the administration of the isotope was taken to be the sow's weight after fasting. A urethral bladder catheter was then inserted after which feed and water were made available to the sows immediately. Urine was collected for $24 \mathrm{~h}$ using $10 \mathrm{ml}$ toluene as a preservative. 


\section{Estimation of $\mathrm{D}_{2} \mathrm{O}$}

Water samples were obtained from samples of sera by means of vacuum sublimation using essentially the method of Vaughan \& Boling (1961). For samples in which sublimation was incomplete the process was repeated in order to avoid the risk of isotopic fractionation.

Concentration of $\mathrm{D}_{2} \mathrm{O}$ in the water recovered was determined by a differential absorption technique using a Pye Unicam SP200 dual-beam infrared spectrophotometer. The method used was similar to that of Foot \& Greenhalgh (1970) but the programme energy control was set at $5 \mathrm{E}$. On each occasion, and for each animal, two samples taken at 2 and $4 \mathrm{~h}$ after the $\mathrm{D}_{2} \mathrm{O}$ infusion were analysed. These were corrected for $\mathrm{D}_{2} \mathrm{O}$ in the serum before the administration of the isotope. The mean of the two corrected values was used as the concentration of $\mathrm{D}_{2} \mathrm{O}$ to calculate $\mathrm{D}_{2} \mathrm{O}$ space as follows:

$$
\mathrm{D}_{2} \mathrm{O} \text { space }(\mathrm{kg})=\frac{\text { weight of } \mathrm{D}_{2} \mathrm{O} \text { infused }(\mathrm{g})}{\text { mean concentration of } \mathrm{D}_{2} \mathrm{O} \text { in two samples }(\mathrm{g} / \mathrm{kg})} .
$$

\section{Analytical methods}

Samples of plasma were analysed for glucose, urea, free fatty acids and phosphorus by the methods of Faulkner (1965), Marsh et al. (1965), Baird et al. (1967) and that of Technicon Instruments Co. Ltd. (1968) respectively. In serum samples, total protein and albumin were determined by the methods of Weichselbaum (1946) and Bartholomew \& Delaney (1966) respectively. Urinary nitrogen was determined by the Kjeldahl method, urea by the procedure of Marsh et al. (1965) and hydroxyproline by the method of Bannister \& Burns (1970). The determination of 3-methylhistidine in urine samples was as described by Harris \& Milne (1981).

\section{Statistical methods}

The standard $t$ test was used to estimate the significance of difference of means in various characteristics between diets, while a split-plot design was used when results at 1 and $8 \mathrm{~h}$ after weaning were compared (Snedecor \& Cochran, 1980).

\section{RESULTS \\ Body-weight changes}

Body-weight changes of the sows during lactation are given in Table 2 and the mean values for each group and those following weaning are shown in Fig. 1. All the animals on the restricted diet lost weight during lactation while all but one of the animals given the ad lib. diet gained weight. Body-weight loss measured before and after fasting of each sow in the week following weaning is shown in Table 3. Weight loss measured before fasting was considerable with that for sows fed $a d \mathrm{lib}$. during lactation being greater than that for sows given a restricted diet. Weight loss measured after fasting was significantly less $(P<0.001)$ than that recorded before fasting but for both measurements differences between the dietary treatments given during lactation were not significant due to large variability between sows given the ad lib. diet.

\section{Losses of body water}

Loss of body water, which is shown in Table 3 , was significantly less $(P<0.05)$ than body-weight loss measured after fasting, regardless of treatment, but losses of water appeared to be large in six of the eight animals. 
Table 2. Body-weights of sows* given one of two diets from $1 d$ post-farrowing, and body-weight changes during lactation $(\mathrm{kg})$

\begin{tabular}{lccc}
\hline \multicolumn{1}{c}{ Diet } & $\begin{array}{c}\text { Sow } \\
\text { no. }\end{array}$ & $\begin{array}{c}\text { Wt at start } \\
\text { of lactation }\end{array}$ & $\begin{array}{c}\text { Wt change during } \\
\text { lactation }\end{array}$ \\
\hline Restricted & 1 & 205 & -1 \\
amounts of & 2 & 212 & -17 \\
concentrate & 3 & 189 & -6 \\
diet & 4 & 193 & -13 \\
Mean & & 200 & $-9 \cdot 25$ \\
SD & 5 & $10 \cdot 6$ & $7 \cdot 14$ \\
Concentrate diet & 6 & 239 & +3 \\
diluted with & 7 & 231 & +15 \\
oat husks and & 8 & 163 & +20 \\
fed ad lib. & & 208 & $+7 \cdot 25$ \\
Mean & & $34 \cdot 7$ & $13 \cdot 0$ \\
SD & & \\
\hline
\end{tabular}

* The sows were paired according to breed and parity as follows: 1 and 5,2 and 6,3 and 7,4 and 8 .

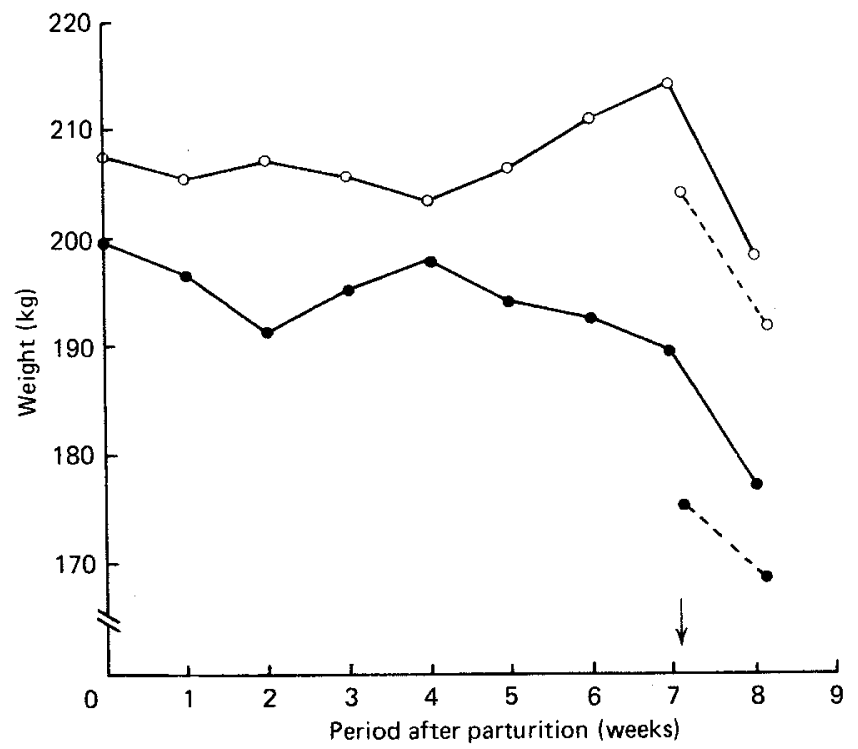

Fig. 1. Mean weight changes of four sows given during lactation either a concentrate diet diluted with $400 \mathrm{~g}$ oat husks $/ \mathrm{kg}$ fed ad lib. $(\mathrm{O}-\mathrm{O})$ or restricted amounts of the concentrate diets $(\bullet-O)$ together with weight changes of each group during 1 week following weaning. (---), For each treatment the post-weaning loss of weight measured after fasting. $\downarrow$, Weaning.

\section{Blood constituents}

Values for seven animals only are considered since attempts to bleed one sow, which had previously been given the restricted diet, $8 \mathrm{~d}$ after weaning were unsuccessful. Pre- and post-feeding values for each animal were obtained as means for the three two-hourly samples taken before and after feeding respectively. The means for all seven animals of these mean values, at 1 and $8 \mathrm{~d}$ after weaning are given in Table 4 . However, for each blood 
Table 3. Weight loss of sows measured before and after fasting and body water loss $(\mathrm{kg})$ in 1 week from the day following weaning

(Each group of four sows received a different diet whilst lactating)

\begin{tabular}{lcccc}
\hline \multirow{2}{*}{$\begin{array}{c}\text { Diet during } \\
\text { lactation }\end{array}$} & $\begin{array}{c}\text { Sow } \\
\text { no. }\end{array}$ & Before fasting & After fasting & Water \\
\cline { 5 - 5 } loss
\end{tabular}

Table 4. Mean concentration of blood constituents before and after feeding in sows at 1 and $8 d$ after weaning

(Mean values with their standard deviations)

\begin{tabular}{|c|c|c|c|c|c|c|}
\hline & \multirow{3}{*}{$\begin{array}{l}\text { Time of } \\
\text { sampling } \\
\text { in relation } \\
\text { to feeding }\end{array}$} & \multicolumn{4}{|c|}{ Period after weaning (d) } & \multirow{3}{*}{$\begin{array}{c}\text { SE of difference } \\
\text { between means } \\
(5 \mathrm{df})\end{array}$} \\
\hline & & \multicolumn{2}{|c|}{1} & \multicolumn{2}{|c|}{8} & \\
\hline & & Mean & sD & Mean & SD & \\
\hline Plasma free- & Before & $0 \cdot 495$ & $0 \cdot 170$ & $0 \cdot 321$ & $0 \cdot 113$ & 0.0835 \\
\hline $\begin{array}{l}\text { fatty acids } \\
(\mathrm{mmol} / \mathrm{l})\end{array}$ & After & $0 \cdot 134$ & 0.029 & $0 \cdot 109$ & 0.033 & 0.0100 \\
\hline Plasma & Before & $4 \cdot 30$ & $0 \cdot 24$ & $4 \cdot 30$ & 0.33 & 0.561 \\
\hline $\begin{array}{l}\text { glucose } \\
(\mathrm{mmol} / \mathrm{l})\end{array}$ & After & $4 \cdot 78$ & 0.43 & 4.95 & $0 \cdot 28$ & $1 \cdot 249$ \\
\hline Plasma urea & Before & $3 \cdot 81$ & 1.02 & $5 \cdot 13$ & $2 \cdot 16$ & $0.473^{*}$ \\
\hline$(\mathrm{mmol} / \mathrm{l})$ & After & $4 \cdot 64$ & $1 \cdot 15$ & $5 \cdot 78$ & 1.85 & $0 \cdot 341^{*}$ \\
\hline Plasma & Before & 1.90 & $0 \cdot 18$ & 1.87 & 0.20 & 0.077 \\
\hline $\begin{array}{l}\text { phosphorus } \\
(\mathrm{mmol} / \mathrm{l})\end{array}$ & After & 1.98 & $0 \cdot 14$ & 1.73 & $0 \cdot 12$ & $0.062^{*}$ \\
\hline Serum total & Before & $84 \cdot 8$ & $7 \cdot 4$ & $85 \cdot 5$ & 4.9 & $2 \cdot 52$ \\
\hline $\begin{array}{l}\text { protein } \\
(\mathrm{g} / \mathrm{l})\end{array}$ & After & $80 \cdot 3$ & $5 \cdot 1$ & $84 \cdot 0$ & $5 \cdot 5$ & 1.97 \\
\hline Serum & Before & $38 \cdot 7$ & 7.2 & $38 \cdot 5$ & $3 \cdot 1$ & $2 \cdot 61$ \\
\hline $\begin{array}{l}\text { albumin } \\
(\mathrm{g} / \mathrm{l})\end{array}$ & After & $38 \cdot 1$ & $6 \cdot 7$ & $37 \cdot 1$ & $2 \cdot 6$ & $2 \cdot 19$ \\
\hline
\end{tabular}

constituent differences in mean values between the two groups of sows were compared and found not to be significant except for concentrations of free fatty acids in samples taken after feeding at $8 \mathrm{~d}$ after weaning (restricted $0.078 \mathrm{v} 0.133 \mathrm{mmol} / 1$ ad lib.).

Concentrations of free fatty acids $1 \mathrm{~d}$ after weaning were appreciably higher than those taken $7 \mathrm{~d}$ later for both pre- and post-feeding measurements but, except for sows on the 

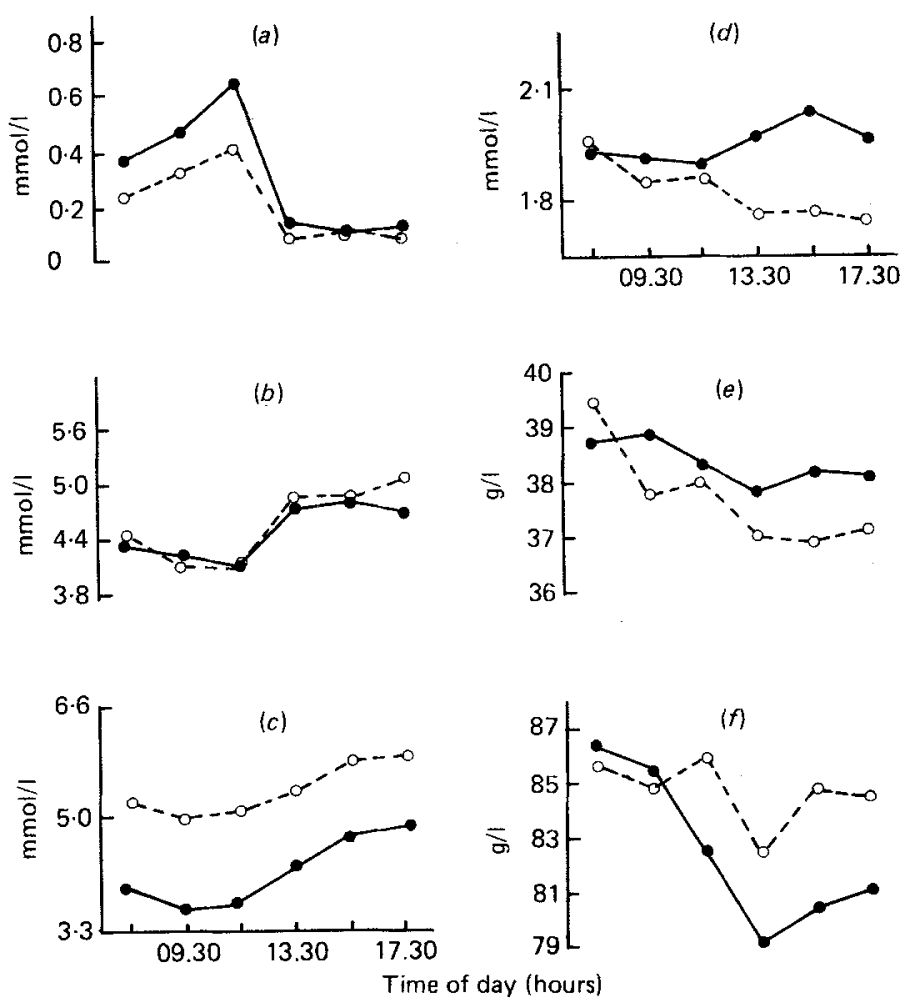

Fig. 2. Concentrations of plasma (a) non-esterified fatty acids, $(b)$ glucose, $(c)$ urea and $(d)$ phosphorus and of serum $(e)$ albumin and $(f)$ total protein in sows during day $1(-0)$ and day $8(O-O)$ after weaning. On each occasion the sows were fed at 11.30 hours.

restricted diet, for samples taken at both times these differences were not significant. Glucose levels on the two different days were similar, but concentrations of plasma urea were on average $30 \%$ higher $(P<0.05)$ at $8 \mathrm{~d}$ after weaning compared with $1 \mathrm{~d}$ after weaning. Values for plasma phosphorus, while similar before feeding on the two different days, were significantly higher $(P<0.05) 1 \mathrm{~d}$ after weaning, when post-feeding measurements were compared.

Levels of serum protein and of serum albumin in samples taken either before or after feeding differed very little between days 1 and 8 after weaning.

Loss of weight in the 1-8 d post-weaning period measured after fasting was significantly correlated to concentrations of serum total protein which were measured before feeding $8 \mathrm{~d}$ after weaning $(r 0.90, P<0.01)$. Loss of body water was also significantly correlated to concentrations of serum total protein measured either before $(r 0.79, P<0.05)$, or after feeding $(r 0.87, P<0.05)$ on the 8th day.

The diurnal variation of blood constituents at 1 and $8 \mathrm{~d}$ after weaning is illustrated in Fig. 2. Plasma levels of free fatty acids measured before feeding in both groups were more variable than those recorded after feeding, but the opposite trend occurred with plasma glucose.

Plasma urea level fell between 4 and $2 \mathrm{~h}$ before feeding, but a slight increase was observed in the majority of sows in both groups in the $2 \mathrm{~h}$ before feeding. The within-treatment fluctuation for plasma urea values for each sow was the smatlest among the various blood characteristics so the sows showed very similar diurnal variations. 
Table 5. Mean excretion of urinary constituents $(\mathrm{g} / \mathrm{d})$ by sows at 1 and $8 d$ after weaning

(Mean values with their standard deviations)

\begin{tabular}{|c|c|c|c|c|c|}
\hline & \multicolumn{4}{|c|}{ Period after weaning (d) } & \multirow{3}{*}{$\begin{array}{c}\text { SE of difference } \\
\text { between means } \\
(6 \mathrm{df})\end{array}$} \\
\hline & \multicolumn{2}{|c|}{1} & \multicolumn{2}{|c|}{8} & \\
\hline & Mean & SD & Mean & SD & \\
\hline Nitrogen & 44.8 & $9 \cdot 3$ & 47.8 & $10 \cdot 00$ & 2.45 \\
\hline Urea & $77 \cdot 3$ & $20 \cdot 9$ & 87.8 & $26 \cdot 3$ & $7 \cdot 34$ \\
\hline Hydroxyproline & 0.325 & $0 \cdot 115$ & 0.308 & 0.111 & 0.074 \\
\hline Creatinine & $5 \cdot 84$ & 0.78 & $6 \cdot 25$ & $1 \cdot 10$ & 0.360 \\
\hline $\begin{array}{l}\text { Hydroxyproline } \\
\text { index* }\end{array}$ & $10 \cdot 42$ & $3 \cdot 00$ & $8 \cdot 85$ & 2.95 & 1.77 \\
\hline
\end{tabular}

* Whitehead (1965).

At both 1 and $8 \mathrm{~d}$ after weaning, there was a marked drop in total protein levels $2 \mathrm{~h}$ after feeding, after which levels increased. A similar pattern of diurnal changes was obtained with concentrations of serum albumin. Diurnal changes in plasma $\mathbf{P}$ were relatively small.

\section{Urinary constituents}

Mean excretions of urinary constituents for all sows in both groups at 1 and $8 \mathrm{~d}$ after weaning are given in Table 5. Differences between the two groups of sows in excretion of each constituent were compared and found not to be significant. However, sows that had been given a restricted diet excreted considerably more $\mathrm{N}$ and urea than did those fed $a d$ lib. at both 1 and $8 \mathrm{~d}$ after weaning. For all sows, differences between days in any constituents were not significant but daily excretion of $\mathrm{N}$, urea and creatinine at $8 \mathrm{~d}$ tended to be higher than that at $1 \mathrm{~d}$ after weaning. The value for hydroxyproline index, on the other hand, which was calculated according to Whitehead (1965), was lower at the later time interval.

It was evident that some of the differences between sows in excretion of $\mathrm{N}$, urea or creatinine were associated with live weight so excretion of each of these constituents per unit of body-weight was compared between the two groups of sows and between values for 1 and $8 \mathrm{~d}$ after weaning. The two groups of sows differed significantly $(P<0.05)$ in $\mathrm{N}$ excretion at $1 \mathrm{~d}$ after weaning and in excretion of urea at both 1 and $8 \mathrm{~d}$ after weaning. No other differences between the groups were significant but for sows fed ad lib., $\mathrm{N}$ excretion at $8 \mathrm{~d}$ after weaning was appreciably higher than the excretion $1 \mathrm{~d}$ after weaning. A similar difference was found in daily excretion of urea and creatinine when expressed on a $\mathrm{g} / \mathrm{kg}$ live weight basis but the differences failed to reach significance.

\section{DISCUSSION}

Sows which were fed $a d$ lib. during lactation and obtained a high intake of digestible energy even though the diet was diluted, lost on average more weight after weaning irrespective of whether the measurements were made before or after fasting. These differences were not significant because of the high variability among sows fed ad lib. and the small number of sows used. Previous workers have observed a considerable weight loss in the newly-weaned sow, which could not be fully explained by a reduction in feed intake during this period, and they related the magnitude of this loss to the plane of nutrition of the sow during the preceding lactation (Lodge, 1959; Lodge et al. 1961; O'Grady et al. 1975). In the present 
study a fairly prolonged period of fasting was applied before the sows were weighed to obtain a fasting weight. As a result, differences in fasted weights between 1 and $8 \mathrm{~d}$ after weaning are unlikely to be due to changes in gut fill. Such differences or losses in weight are most likely to reflect the losses of body tissues. Thus all eight sows in the present study probably lost significant amounts of body tissue, with the magnitude of the loss in two sows, both of which were fed ad lib. during lactation, being exceptionally large.

Body water losses appeared to be considerable in six of the eight animals. However, this loss was significantly less than body-weight loss $(P<0.05)$ measured in fasted animals, which indicates that, apart from water, other tissue components may have been lost following weaning. Protein and water are frequently associated together in the proportion $1: 3.4$ because of the chemical composition of muscular and other tissue, so the fasted weight losses may have been composed mainly of these two components.

Measurements of body water made in the present study however, cannot be regarded as absolute and some care is required in their interpretation. Houseman et al. (1973) found that $\mathrm{D}_{2} \mathrm{O}$ space over-estimated by $2.2 \%$ TBW measured by drying. Other workers (Foot \& Greenhalgh, 1970; Trigg, 1974; Houseman et al. 1978) have also reported that $\mathrm{D}_{2} \mathrm{O}$ space over-estimates TBW so it is likely that such a bias occurred in the present work. However, over-estimates of body water in this study should not affect appreciably the body water loss obtained by difference provided any bias was consistent between determinations of $D_{2} \mathrm{O}$ space. Every effort was made to standardize procedures so it is felt that the measured loss of body water was close to the true loss which on average was a large fraction of the fasted weight loss occurring in sows post-weaning.

There is some evidence which suggests that a considerable part of any body water lost following weaning may come from the circulatory system, i.e. the blood. Anderson et al. (1970), using three gilts, measured plasma volume at approximately 20 dintervals throughout their pregnancy and, in two of these gilts, during lactation. They found that the plasma volume in lactation was approximately 41 greater than that at the beginning of pregnancy. They reported that the pattern of change in plasma volume during lactation was very similar to that of the milk yield. Van Kempen \& Grimbergen (1977) suggested that the blood volume of the sow during lactation is subject to changes and it is likely that the water corresponding to the increase of plasma volume during lactation and related to the milk yield of the animal is later lost after weaning. Any decrease in plasma volume may, of course, affect the concentration of a constituent, and this possible effect together with a lack of information on the blood chemistry of pigs which are losing weight makes the results of the present study difficult to interpret. The diurnal variations obtained reveal a considerable fluctuation in most of the blood constituents studied. It is recommended that if repeated sampling on the same day is not feasible, the same time in relation to feeding should be used to withdraw blood samples. An examination of the diurnal variation of blood constituents in this study suggests that gluconeogenesis may occur as the time from feeding increases. Plasma levels of free fatty acids decreased sharply after feeding and remained at a constant level until $6 \mathrm{~h}$ post-feeding when the last sample was taken. Cunningham (1971) reported that pigs metabolize practically no energy of endogenous origin until approximately $6 \mathrm{~h}$ after feeding. Plasma levels of urea increased steadily up to $4 \mathrm{~h}$ post-feeding, a similar dependence of plasma urea on time after feeding being reported by Eggum (1976).

The difference between 1 and $8 \mathrm{~d}$ after weaning in concentrations of plasma free-fatty acids and plasma urea suggests that a lower mobilization of fat and a greater mobilization of protein was taking place at the later time interval. Some support for the greater protein depletion was obtained from the values for the daily excretion of urinary $\mathrm{N}$, urea and creatinine which were higher $8 \mathrm{~d}$ after weaning and the differences in excretions between the $2 \mathrm{~d}$ were large when expressed on a per $\mathrm{kg}$ body-weight basis. The hydroxyproline index 
however, was lower $8 \mathrm{~d}$ after weaning. This index was found to be lower in malnourished children and it has been suggested that the index may be used to indicate marginal cases of malnutrition (Whitehead, 1967). If any analogy exists between weaned sows and malnourished children in this respect, the change of the hydroxyproline index between 1 and $8 \mathrm{~d}$ after weaning supports the concept of some depletion of body protein.

Unfortunately, there is no information in the literature regarding the extent to which the newly-weaned sow can mobilize body protein. However, it is a distinctive feature of the sow's metabolism during lactation so that she can maintain her milk production when dietary protein is reduced by depleting her body protein reserves (Salmon-Legagneur, 1965). In the lactating sow the protein of muscle, intestinal mucosa and liver are particularly responsive to the over-all needs of the animal. It is possible that the additional musculature acquired in the abdominal wall of the sow during pregnancy (Heap \& Lodge, 1967) is also utilized as a labile protein store during lactation. It is possible that such a breakdown of muscle protein continues for a while after weaning. It was unfortunate that an attempt to show such an effect through the measurement of the excretion of 3-methylhistidine was subsequently shown to be inappropriate (Harris \& Milne, 1981).

Alternatively, changes in the hormonal status of the animal or the occurrence of stress, either or both of which could be caused by removal of the litter, may give rise to losses of body tissues which would include protein. Clearly further work is desirable to confirm or refute the trends shown in this study. To obtain an accurate measure of losses of body protein a comparative slaughter study using a large number of sows may be required.

The authors thank Messrs G. McConnachie and O. McPherson for help with the care of the animals and Mr A. Cadenhead and Dr M. F. Fuller of the Rowett Research Institute for advice on sampling techniques.

\section{REFERENCES}

Anderson, D. M. \& Elsley, F. W. H. (1969). Journal of Agricultural Science, Cambridge 72, $475-477$.

Anderson, D. M., Elsley, F. W. H. \& McDonald, I. (1970). Quarterly Journal of Experimental Physiology 55, 293-300.

Baird, J. D., Black, M. W. \& Faulkner, D. E. (1967). Journal of Clinical Pathology 20, 905-909.

Bannister, D. W. \& Burns, A. B. (1970). Analyst, London, 95, 596-600.

Bartholomew, R. J. \& Delaney, A. M. (1966). Proceedings of the Australian Association of Clinical Biochemists 1, 214-217.

Bowland, J. P. (1967). Journal of Animal Science 26, 533-539.

Cunningham, H. M. (1971). Canadian Journal of Animal Science 51, 341-350.

Eggum, B. O. (1976). In Protein Metabolism and Nutrition, pp. 249-258. [D. J. A. Cole, K. N. Boorman, P. J. Buttery, D. Lewis, R. J. Neale and H. Swan, editors]. London: Butterworths.

Faulkner, D. E. (1965). Analyst, London 90, 736-744.

Foot, J. Z. \& Greenhalgh, J. F. D. (1970). British Journal of Nutrition 24, 815-825.

Harris, C. I. \& Milne, G. (1981). British Journal of Nutrition 45, 423-429.

Haverberg, L. N., Omstedt, P. T., Munro, H. N. \& Young, V. R. (1975). Biochimica et Biophysica Acta 405, $67-71$.

Heap, F. C. \& Lodge, G. A. (1967). Animal Production 9, 237-245.

Houseman, R. A., McDonald, I. \& Pennie, K. (1973). British Journal of Nutrition 30, 149-156.

Houseman, R. A., Robinson, J. J. \& Fraser, C. (1978). Proceedings of the Nutrition Society 37, 64A.

Lodge, G. A. (1959). Journal of Agricultural Science, Cambridge 53, 177-191.

Lodge, G. A., McDonald, I. \& MacPherson, R. M. (1961). Animal Production 3, 269-275.

Marsh, W. H., Fingerhut, B. \& Miller, H. (1965). Clinical Chemistry, 11, 624-627.

O'Grady, J. F., Elsley, F. W. H., MacPherson, R. M. \& McDonald, I. (1975). Animal Production 20, $257-265$.

Salmon-Legagneur, E. (1965). Annales de Zootechnie 14, 5-137.

Snedecor, G. W. \& Cochran, W. G. (1980). Statistical Methods, 6th ed. Ames, Iowa: Iowa State University Press.

Technicon Instruments Co. Ltd (1968). Technicon Methodology Sheet N4C. Basingstoke: Technicon Instruments Co. Ltd. 
Trigg, T. E. (1974). Body composition of ruminants in relation to plane of nutrition and production. PhD Thesis, University of Aberdeen.

Van Kempen, G. J. M. \& Grimbergen, A. H. M. (1977). Zeitschrift für Tierphysiologia Tierernährung und Futtermittekunde 38, 158-173.

Vaughan, B. E. \& Boling, E. A. (1961). Journal of Laboratory and Clinical Medicine 57, 159-164.

Weichselbaum, T. E. (1946). American Journal of Clinical Pathology 16, 40-44.

Whitehead, R. G. (1965). Lancet ii, 567-570.

Whitehead, R. G. (1967). Archives of Diseases in Childhood 42, 479-484.

Young, V. R., Alexis, S. C., Balinga, B. S., Munro, H. N. \& Mueke, W. (1972)'. Journal of Biological Chemistry 247, 3592-3600.

Zoiopoulos, P. E., English, P. R. \& Topps, J. H. (1982). Animal Production 35, 25-33.

Zoiopoulos, P. E., Topps, J. H. \& English P. R. (1978). Proceedings of the Nutrition Socieity 37, 77A. 